\title{
Stock Price Synchronicity and Current and Potential Credit Ratings
}

\author{
Bruno Figlioli ${ }^{1}$, Rafael Moreira Antônio ${ }^{1}$ \& Fabiano Guasti Lima ${ }^{1}$ \\ ${ }^{1}$ School of Economics, Business Administration and Accounting at Ribeirão Preto, University of São Paulo, \\ Brazil \\ Correspondence: Bruno Figlioli, School of Economics, Business Administration and Accounting at Ribeirão Preto, \\ University of São Paulo, Brazil; Accounting Department. Av. Bandeirantes, 3.900. Monte Alegre, Ribeirão \\ Preto/SP, Zip Code: 14.040-905, Brazil. Tel: 55-16-3315-3899. E-mail: figlioli@usp.br
}

Received: August 1, 2019

Accepted: August 19, 2019

Online Published: September 8, 2019

doi:10.5539/ijef.v11n10p1

URL: https://doi.org/10.5539/ijef.v11n10p1

\begin{abstract}
This study examines whether the stock prices reflet the relevant information on the companies'current and potential credit ratings. This investigation was carried out from the construct of stock price synchronicity, that is, the more the stock prices reflect the specific information of a certain company, the less the synchronicity of these prices in relation to the market general information tends to be. It would imply that the stock prices tend to be more informative on the companies'potential in generating future economic benefit and on their risk levels. For carrying out this study, information on the companies which have their shares listed at the Brazilian Stock Exchange (Brazil, Stock Exchange and Over-the-counter - B3) from 2010 to 2015 were analyzed. The results obtained point that the stock prices not only embody information on the alterations of the companies's current credit ratings regarding the upgrade, but also reflect, with certain antecipation, the potential credit ratings. Nevertheless, the results indicate that not every credit rating class is associated with relevant information for the capital market.
\end{abstract}

Keywords: synchronicity, credit ratings, upgrades, downgrades, capital market

\section{Introduction}

The risk-rating agencies, through the disclosure of the companies'credit ratings, signal for different types of economic agents, such as investors and creditors, past and prospective information on the economic and financial performance of these organizations (Alissa, Bonsall, Koharki, \& Penn, 2013). Thus, the credit ratings would be important implications for the companies and, in this line, Galil and Soffer (2011) highlight that risk-rating agencies are financial information source and that the ratings are used in risk management and in the management and formation of investment portfolios. Another example is that the credit risk impact on the managers' decision regarding the companies'capital structure (Hung, Banerjee, \& Meng, 2017; Kisgen, 2006; Pan, Lin, Lee \& Ho, 2015), access to the credit market (Tang, 2009), stock price quotations for the innitial public offerings in the capital market (IPO- Initial Public Offering) (An \& Chan, 2008), among other aspects.

Moreover, the credit ratings are criticized for not capturing, necessarily, the potential risks associated with the generation of the companies' future economic benefits. Besides, the review of the rating level by the risk-rating agencies is usually slow, and does not timely embody the companies'characteristics in this risk-rating process (Driss, Massoud, \& Roberts, in press). Furthermore, Stolper (2009) highlights that many times it is argued that the credit rating agencies have incentives to atribute inflated ratings (optimism later reported by Jollineau, Tanlu and Winn (2014) and Fracassi, Petry and Tate (2016) as well).

For the capital market, this kind of gap between the companies'current and potential ratings represents a relevant matter to be examined. On the other hand, the investment on shares can follow specific rules according to the ratings taken by the companies. Some investment funds, for instance, restrict the allocation of funds in companies which are not rated with speculative grade by the risk-rating agencies. On the other hand, when considering that the capital market is informationally efficient, in order to incorporate all the relevant information almost instantaneously, as advocated by Fama (1970), the stock prices may reflect the companies' potential ratings. Cantor (2004), however, highlighted that a great literature has explored the relationship between the ratings, the spreads of securities and the stock prices and pointed out that: i) negative rating events (announcement of downgrade, for instance) lead to statistically significant movements in the prices or in the 
spreads; ii) positive rating events lead to smaller and less significant movements in the prices or in the spreads; and, that iii) despite the fact that the rating events cause significant price changes, these changes are, usually, economically insignificant.

One of the ways to examine whether the stock prices reflect the companies'current and potential is through the synchronicity constructo. According to Roll (1988), the stock prices are formed by a set of specific information of the company and more general information, arising from the market as a whole. The more the stock prices embody the companies'specific information to the detriment of market information, the better the quality of the stock prices would be in reflecting the companies'potential in generating future economic benefits and their risks. Thus, the stock prices would present low synchronicity with the market.

That said, the present study aims to answer the following question: are the synchronicity levels of the stock prices traded at the Brazilian Stock Exchange - (B3) associated with the companies'current and potential ratings?

For the conduct of the study, quarterly information on the companies'credit ratings from two risk-rating agencies: Standard \& Poor's (S\&P) and Moody's was used. Additionally, accounting and market information of the companies under study was collected. The period of analysis goes from 2010 to 2015.

An important characteristic of the sample of the present study is that it considers just the Brazilian scenario. It can lead to less generalization of the results; however, the results tend to be more robust since there is the control of matter which involves the efficiency level of capital market, regulatory environment, ownership rights and economic (micro and macroeconomic) conditions in the Brazilian context in a more suitable way.

The data were analyzed by means of panel data linear regressions. The results obtained evinced: i) the positive alterations of the companies'ratings (upgrades) are negatively associated with the synchronicity levels of the stock prices. This result was found for the companies rated by the agencies as investment grade; ii) no significant results were found when there are negative alterations of the companies'ratings (downgrades) with the synchronicity levels of the stock prices and; iii) the stock prices tend to embody information regarding the companies'potential ratings.

A plausible explanation for the result related to the credit ratings upgrades is that the market would be pricing the business decisions regarding the objectives traced by them to reach better classification in the ratings. In regard of the downgrades, the investors may assume that this kind of credit ratings alteration does not pertain to a persistent situation for a certain company. Finally, there were evidences that the capital market, through the information brought by the stock prices, can provide additional information on the companies ratings (potential ratings) compared to the current ratings.

The results reached in the present study bring important contributions to the investors and risk-rating agencies. For the current and potential investors, it may bring useful information regarding the role performed by the companies'credit ratings as informational asymmetry reducer. For instance, Hung et al. (2017) point that a greater informational asymmetry (between managers and investors) may generate incentives so that the companies'managers raise the level of financial leverage in prior periods, but which are close to, the announcement of rating downgrade. For the risk-rating agencies, the results obtained may be useful in identifying whether the credit ratings result in relevant information to the several economic agents regarding the decision-making process.

This paper is divided in five sections. The first one refers to this introduction. The second and third ones are, respectively, the theoretical foundation and the methodological aspects. The presentation and analysis of the results take place in the fourth section. The final considerations are presented in the fifth section.

\section{Theoretical Foundation}

\subsection{Current and Potential Credit Ratings}

According to Hovakimian, Kayhan and Titman (2009), the credit rating can be defined as an ordinal scale which seeks to evince the probability of non-payment of financial liabilities (default) for a specific credit borrower. For Bolton, Freixas and Shapiro (2012), the credit ratings represent an important risk measure of the companies, mainly for the less sophisticated financial market participants regarding the collection and analysis of relevant information. Whereas, for Galil and Soffer (2011), the ratings help in the risk management and the formation of investment portfolios and for Antônio et al. (2019) the rating represent a judgment of the credit analysts and rating agencies of certain companies accompanied by them.

Even though the companies'credit risk measurement is subjected to criticism: the risk-rating process would be biased for emerging countries compared to the United States of America (Luitel, Vanpée, \& Moor, 2016); the 
exaggerated optimism and pessimism of the credit analysts impact the credit ratings level (Fracassi et al., 2016); the ownership concentration (large shareholders) of risk-rating companies may be a factor which influences their timely decisions (Kedia, Rajgopal, \& Zhou, 2017); the credit ratings reviews are not timely (Hung et al., 2017), among other criticisms.

A desirable characteristic for the companies ratings scale is that it should envisage all the relevant information on the default probability, that is, future alterations of credit ratings should not be associated with publicly available information (Hovakimian et al., 2009). Also according to Hovakimian et al. (2009), the risk-rating agencies tend to procrastinate the companies ratings update up to the moment the risk profile is clear. In this context, the credit ratings may be correlated to observable variables of the companies'economic and/or financial performance. There would be, therefore, a distinction between current and potential credit ratings.

As an example of this relationship between the current and potential credit ratings, the study of Alissa et al. (2013) sought tho identify how the discretion of the managers in the acknowledgment and measurement of accounting information influenced the alterations in credit ratings. The authors found evidences of manipulation of the accounting results for the companies with greater differences between the current and potential ratings. Graham and Harvey (2001) study point rising financial costs for the companies in which the current credit ratings do not converge to their potential credit ratings along the time. Hung et al. (2017) state that the companies'managers (insiders) have incentives in adjusting the level of the capital structure, since they have privileged information of the credit ratings alterations compared to the investors (outsiders).

Nevertheless, a question presented is whether the credit ratings, current or potential, are priced in the capital market. That is, if this kind of information interact in the formation of investors'expectations regarding the companies'potential in generating future economic benefits and their risks. This matter will be examined by the synchronicity construct.

\subsection{Synchronicity}

According to Roll (1988), the stock prices are formed both by the companies's specific information and the market information as a whole. If the stock prices reflect a greater amount of specific information in detriment to market information, the better the informational quality of the stock prices (low synchronicity) tends to be. Thus, empirical works have demonstrated that several factors would be related to the stock price synchronicity levels (SPSL).

Morck, Yeung, and Yu (2000) suggest that the SPSL tend to be greater for the less developed countries compared to the developed ones. The authors attribute such result to the low protection levels to the ownership rights seen in less developed markets.

The study developed by Jin and Myers (2006), carried out from a 40-country sample from 1990 to 2001, found evidences that corporate governance measures are negatively related to the SPSL. On the other hand, Fernandes and Ferreira (2008) found evidences of a lower synchronicity level for the companies which trade their shares both in the domestic and North American markets, through the American Depositary Receipts (ADRs). This result was robust only for the sample of countries rated as developed.

Kim and Shi (2012) and Wang and Wu's (2015) studies relate the SPSL to the adoption of the international accounting standards of the International Financial Reporting Standards (IFRS) and suggest that the IFRS adoption brought more relevant accounting information in the investors'decision-making process, which contributes to the reduction in the SPSL.

Elshandidy (2014) and Hasan, Song and Wachtel (2014) understand that the SPSL can be used as a measure of the development of financial markets in less developed countries. An example of that is China, which has been persistently decreasing the SPSL in the recent years. Marcet (2017) points that the SPSL for the Latin America countries (LA) tend to be higher for the companies which are analyzed by a very restricted group of foreign analysts who cover these countries. Also in the context of LA, Figlioli and Lima (2019) identified that the average SPSL tends to rise in periods of market turmoil, which culminates in a noisy process of stock price formation during financials crises or economic recessions.

In the Brazilian scope, the high concentration of the companies voting capital which trade their shares in the exchange market, the low legal enforcement and ownership rights, as pointed by Lopes (2006) and Ghio and Verona (2015), can be factors which restrict the magnitude of the companies relevant information and which could be reflected on the stock prices. Thus, it is still not clear whether the companies'credit ratings are priced in whole or just marginally by the capital market, specially for the companies which are in less developed countries (Hammami \& Bahri, 2016; Salvador, 2017). 


\subsection{Study Hypotheses}

The present study has tested the SPSL with three current and potential credit ratings of the companies. In order to do so, three hypotheses were developed, described next in their alternative form:

Hypothesis $1\left(\mathbf{H}_{1}\right)$ : the companies'positive credit ratings alterations (upgrades) are negatively related to the SPSL.

Hypothesis $2\left(\mathbf{H}_{2}\right)$ : the companies'negative credit ratings alterations (downgrades) are negatively related to the SPSL.

Hypothesis $3\left(\mathbf{H}_{3}\right)$ : the companies' potential credit ratings are negatively related to the SPSL.

The Hypotheses 1 and 2 (H1 and H2) tested whether the SPSL embody information of the companies's current credit ratings alterations (upgrades and downgrades). The Hypothesis 3 (H3) tested whether the SPSL embody relevant information regarding the companies' potential credit ratings.

For the Hypotheses 1 to 3, an inverse relationship between the SPSL and the current and potential credit ratings was expected. The explanation for this inverse relationship is that if current or potential credit ratings are relevant information for investor decision-making, stock prices tend to reflect such information to the detriment of more general market information, which implies a reduction in SPSL levels. In this sense, these results would bring evidences that the stock prices embody the companies' probabilities of default.

\section{Method}

\subsection{Data Collection and Sample}

The data necessary for carrying out this study were collected from two distinct sources: the database of the Thomson Reuters ${ }^{\mathrm{TM}}$ information system and Economatica ${ }^{\circledR}$. In the Thomson Reuters ${ }^{\mathrm{TM}}$ database, information regarding the companies'credit ratings was collected. These ratings result from the risk-rating agencies Standard \& Poor's (S\&P) and Moody's. In the Economatica ${ }^{\circledR}$ database, accounting and market information of the companies under study was gathered. Moreover, the data collected were in a quarterly basis and they refer to the 2010-2015 period.

For the composition of the sample, data exclusion criteria was used: i) the information for the periods when there were not all the necessary data for the conduction of the statistical and econometric tests was not considered; ii) the periods in which certain company presented negative net equity were eliminated, since the results of the present study are based on the assumption of the companies'continuity (going concern); iii) the representative data of the financial sector were purged; iv) for the companies which have more than one kind of stock listed at the B3 (common and preferred), only the information of the stocks with higher negotiability level within the period of analysis (2010 to 2015) was considered. This procedure aimed to avoid duplication of information on a same company in composing the sample and; v) the outliers were purged from the sample by the leverage statistics, as proposed in Cameron and Trivedi (2010).

With the data exclusion procedure, the sample remained with the total of 828 observations and, still, included 14 sectors of the companies'economic activity. Table 1 presents the structure of the sample.

Table 1. Sample structure according to the companies'economic activity

\begin{tabular}{lccc}
\hline \multicolumn{1}{c}{ Sector } & Observations & Simple Frequency & Accumulated Frequency \\
\hline 1-Agriculture and Fishing & 18 & $2.17 \%$ & $2.17 \%$ \\
2-Food and Beverages & 126 & $15.22 \%$ & $17.39 \%$ \\
3-Commerce & 36 & $4.35 \%$ & $21.74 \%$ \\
4-Construction & 108 & $13.04 \%$ & $34.78 \%$ \\
5-Mining & 36 & $4.35 \%$ & $39.13 \%$ \\
6-Others & 126 & $15.22 \%$ & $54.35 \%$ \\
7-Pulp and Paper & 54 & $6.52 \%$ & $60.87 \%$ \\
8-Extraction of Oil and Gas & 36 & $4.35 \%$ & $65.22 \%$ \\
9-Chemical & 36 & $4.35 \%$ & $69.57 \%$ \\
10-Steelmaking and Metallurgy & 72 & $8.70 \%$ & $78.26 \%$ \\
11-Software and Data & 18 & $2.17 \%$ & $80.43 \%$ \\
12-Telecommunication & 36 & $4.35 \%$ & $84.78 \%$ \\
13-Transportation & 90 & $10.87 \%$ & $95.65 \%$ \\
14-Automobiles and Parts & 36 & $4.35 \%$ & $100.00 \%$ \\
\multicolumn{1}{c}{ Total } & 828 & - & - \\
\hline
\end{tabular}

Source: Elaborated by the authors. 


\subsection{Econometric Modeling}

The SPSL construct was operationalized by means of a market model. This kind of econometric model relates the representative returns of the market portfolio and the returns related to the companies' economic activity sector (independent variables) to the share returns (dependent variable). Nevertheless, the development of this econometric modeling followed Chan and Hammeed (2006) recommendations. For the authors, the SPSL calculation must embody, in regard of the emerging countries, just representative information of the market portfolio. For these countries, there would be a high sectorial concentration, which restricts the use, in the market model, of information pertinent to the companies'economic activity sector. This econometric modeling was defined as follows:

$$
R_{i t}=\alpha+\beta_{1} R M_{t}+\varepsilon_{t}
$$

In which: $\mathrm{R}_{\mathrm{it}}$ : stock return $\mathrm{i}$ for the period $\mathrm{t} ; \mathrm{RM}_{\mathrm{t}}$ : market protfolio return for the period $\mathrm{t}$. The Ibovespa benchmark returns as representative of the market portfolio returns and; $\varepsilon_{t}$ : error term.

For each quarter and stock analyzed, the results of the market model (Model 1) were obtained by means of linear regressions. Afterwards, a logistical transformation of the coefficients of determination $\left(\mathrm{R}^{2}\right)$ obtained in Model 1 , as proposed by Morck et al. (2000) and Chan and Hameed (2006) was performed. This formulation is, thus, defined:

$$
\operatorname{Sinc}_{i t}=\ln \left(\frac{R_{i t}^{2}}{1-R_{i t}^{2}}\right)
$$

in which: Sincit: stock price synchronicity $i$ for the period $t$; $\ln$ Napier's logarithm and; $\mathrm{R}^{2}$ it coefficient of determination for the company $i$ in the period $t$.

For the calculation of the companies' potential credit ratings a set of variables, aiming to measure the probability a certain company takes on the investment grade was used. This procedure allowed to identify the companies'different probabilities of taking on the investment grade, even within a single credit rating level (current). Thus, a Probit model in panel data was used. This formulation is defined as follows:

$$
\text { RatingPot }_{i t}=\alpha+\beta_{n} X_{i t}+\varepsilon_{t}
$$

in which: RatingPot ${ }_{i t}$ : binary variable representative of the potential credit rating for the company $i$ in the period $t$. It takes on the value 1 for the credit ratings rated as investment grade by the risk-rating agencies (S\&P and Mood's). It takes on the value 0 for the other observations; $X_{\mathrm{it}}$ : variable vector for the company $\mathrm{i}$ in the period $\mathrm{t}$ and; $\varepsilon_{t}$ : error term.

The independent variables used in the Model $3\left(X_{\mathrm{it}}\right)$ were based on the works of Alissa et al. (2013), Hovakimian et al. (2009), Brito, Assaf and Corrar (2009) and Balios, Thomadakis and Tsipouri (2016) and are presented in

\begin{tabular}{|c|c|c|}
\hline Variable & Description & Formula \\
\hline Apl_Financ ${ }_{\mathrm{CP}}$ & Short-term Investments & $\ln \left(\frac{\text { Apl_Financ }_{C P}}{A T}\right)$ \\
\hline NwC & Net Working Capital & $\ln \left(\frac{A C-P C}{A T}\right)$ \\
\hline $\mathrm{DPR}_{\mathrm{CP}}$ & Short-term Debts to related parties & $\ln \left(\frac{D P R_{C P}}{A T}\right)$ \\
\hline $\mathrm{DPR}_{\mathrm{LP}}$ & Long-term Debts to related parties & $\ln \left(\frac{D P R_{L P}}{A T}\right)$ \\
\hline Emp_Financ $_{\mathrm{CP}}$ & Short-term Loans and Financing & $\ln \left(\frac{E m p_{C P}+\text { Financ }_{C P}}{A T}\right)$ \\
\hline Emp_Financ $_{\mathrm{LP}}$ & Long-term Loans and Financing & $\ln \left(\frac{E m p_{L P}+\text { Financ }_{L P}}{A T}\right)$ \\
\hline Fex_Op & Cash flow generated by operating activities & $\ln \left(\frac{F c x_{-} O p}{A T}\right)$ \\
\hline Imob & Fixed Assets & $\ln \left(\frac{\operatorname{Imob}}{A T}\right)$ \\
\hline LAJIR_DF & Capacity of payment of Financial costs & $\ln \left(\frac{L A J I R}{D F}\right)$ \\
\hline
\end{tabular}
Table 2.

Table 2. Variables used in the calculation of the probabilities of the potential credit ratings 


\begin{tabular}{llc}
\hline DIV_AÇÃO & Dividend per share & DIV \\
MV & Market value of the companes \\
\hline
\end{tabular}

ln: Naiper's logarithm; Apl_Financ ${ }_{\mathrm{CP}}$ : short-term investments; AC: working capital; PC: current liabilities; DPR $_{\mathrm{cp}}$ : short-term debts to related parties; $\mathrm{DPR}_{\mathrm{LP}}$ : long-term debts to related parties; $\mathrm{Emp}_{\mathrm{CP}}$ : short-term loans; Emp $_{\mathrm{LP}}$ : long-term loans; Financ $\mathrm{CP}_{\mathrm{C}}$ short-term financing; Financ $\mathrm{LP}_{\mathrm{P}}$ long-term financing; Fcx_op: cash flow generated by operating activities; Imob: fixed assets; LAJIR: earnings before interests and taxes; DF: financial costs; DIV: dividend per share; Quant_Ações: number of outstanding shares; VM: market value of the companies'net equity and; AT: average total assets.

Source: Elaborated by the authors.

Afterwards, the Hypotheses 1, 2 and $3\left(\mathrm{H}_{1}, \mathrm{H}_{2}\right.$ and $\left.\mathrm{H}_{3}\right)$ were tested using the variable Sincit (Model 2) and, also, by the probabilities obtained by means of the Model 3, which refer to the companies analyzed taking on the investment grade. For the tests of the hypotheses 1 and 2, the Logit model in panel, which separated the results according to the types of the alterations of the companies' credit ratings (upgrades and downgrades), was used. This econometric model is defined as:

$$
\begin{gathered}
A L T_{R A T_{i t}}=\alpha+\beta_{1} \text { Sinc }_{i t}+\beta_{2} \text { Sinc }_{i t} \times G I+\beta_{3} \text { Probab }_{G I_{i t}}+\beta_{4} \text { Beta }_{i t}+\beta_{5} \text { Price }_{P L_{i t}}+ \\
\beta_{6} \text { ROI }_{i t}+\beta_{7} \text { Crisis }+\varepsilon_{t}
\end{gathered}
$$

in which: ALT_RAT: by variable representative of the credit ratings alterations of the company $\mathrm{i}$ in the period t. It takes on the value 1 for upgrades and downgrades (these types of alterations were assessed separately). It takes on the value 0 for the periods in which there were no alterations in the credit ratings; Sincit: synchronicity level of the price of the stock $i$ for the period $t$; GI: binary variable which takes on value 1 for the credit ratings of the companies rated as investment grade. It takes on value 0 for the other observations; Probab_GI $\mathrm{it}_{\mathrm{it}}$ : probability of the credit rating for the company $\mathrm{i}$ for the period $\mathrm{t}$ in taking on the investment grade; Betait: market beta coefficient for the company $\mathrm{i}$ in the period $t$. The market beta coefficient was calculated for a three-month period; Price_PL $L_{\mathrm{it}}$ : ratio between the stock price and the net equity per share; $\mathrm{ROI}_{\mathrm{it}}$ : average return on investment of company $\mathrm{i}$ for the period $\mathrm{t}$; Crisis: binary variable which takes on the value 1 for the observations which refer to the years 2014 and 2015 It takes on the value 0 for the other observations and; $\varepsilon_{t}$ : error term.

For the model 4 , it was expected that the coefficients $\beta_{1}$ and $\beta_{2}$, which are related to the SPSL, present negative sign and statistical significance, both for the upgrades and downgrades. This result would bring evidences that the capital market, by means of SPSL reduction, captures the alterations in the companies'credit ratings. Regarding the upgrades, coefficients which positive signs for the variables Probab_Glit, Price_PLit and ROIit and coefficients with negative signs for the variables Beta ${ }_{\mathrm{it}}$ and Crisis were expected. Regarding the downgrades, coefficients with signs opposite to the ones of the upgrades were expected. A remark for the Model 4 was the use of the variable Crisis, which sought to capture periods of greater turbulence in the Brazilian financial markets. According to data made available by the Instituto Brasileiro de Geografia e Estatística (IBGE, 2017), there was strong contraction of the Gross Domestic Product (GDP) for the 2014-2015 period.

Regarding the test of the Hypothesis 3, the variable Probab_Glit was taken as dependent variable and examined from a Tobit model. The use of the Tobit model is justified due to the fact that the probabilities obtained in Model 3 are limited to the value range from 0 to 1 . This econometric model is defined as:

$$
\begin{gathered}
\text { Probab }_{G I}=\alpha+\beta_{1} \text { Sinc }_{i t}+\beta_{2} \text { Sinc }_{i t} \times G I+\beta_{3} \text { Beta }_{i t}+\beta_{4} \text { Price }_{P L i t}+\beta_{5} \text { ROI }_{i t}+ \\
\beta_{6} \text { Concent_AC }_{i t}+\beta_{7} \text { Intang }_{i t}+\varepsilon_{t}
\end{gathered}
$$

in which: Probab_Glit: probability of the credit rating of company $i$ for the period $t$ in taking on the investment grade; Sincit: synchronicity level of the price of the stock i for the period t; GI: binary variable which takes on value 1 for the credit ratings of the companies rated as investment grade. It takes on value 0 for the other observations; Beta $\mathrm{i}_{\mathrm{it}}$ : market beta coefficient for the company $\mathrm{i}$ in the period $\mathrm{t}$. The market beta coefficient was calculated for a three-month period; Price_PLit: ratio between the stock price and the net equity per share; ROIit: average return on investment of company $i$ and for the period t; Concent_ACit: concentration level of the voting capital of company $i$ for the period t. For the calculation of this variable, the average accumulated participation of the main three shareholders in the companies'voting capital was considered; Intangit: percentage of the intangible assets in relation to the total assets. For this variable, the logarithmic scale was used and; $\varepsilon_{t}$ : error term.

For the model 5, it was expected that the coefficients $\beta_{1}$ and $\beta_{2}$, which are related to the SPSL, presented 
coefficient with negative sign and statistical significance. It would indicate that the stock prices embody information on the companies potential credit ratings. Moreover, the results can point that the capital markets can foresee the ratings alterations. For the variables Betait and Concent_ACit coefficients with negative signs were expected. For the other variables of the Model 5, coefficients with positive signs were expected.

\section{Presentation and Discussion of the Results}

The descriptive statistics of the variables used in the present study are presented in Table 3.

Table 3. Descriptive statistics

\begin{tabular}{|c|c|c|c|}
\hline \multicolumn{4}{|c|}{ Panel A: Variables used in Model 3: potential credit ratings calculation } \\
\hline Variables & Average & Standard Deviation & $\begin{array}{c}\text { Coefficient of Variation } \\
\text { Absolute Value }\end{array}$ \\
\hline Apl_Financ ${ }_{\mathrm{CP}}$ & -3.632 & 1.505 & 0.414 \\
\hline NWC & -2.197 & 0.969 & 0.441 \\
\hline $\mathrm{DPR}_{\mathrm{CP}}$ & -6.162 & 1.783 & 0.289 \\
\hline $\mathrm{DPR}_{\mathrm{LP}}$ & -6.934 & 2.393 & 0.345 \\
\hline Emp_Financ $_{\mathrm{CP}}$ & -2.889 & 0.830 & 0.287 \\
\hline Emp_Financ ${ }_{L P}$ & -1.546 & 0.679 & 0.439 \\
\hline Fcx_Op & -2.942 & 0.965 & 0.328 \\
\hline Imob & -2.063 & 1.662 & 0.806 \\
\hline LAJIR_DF & 2.611 & 10.762 & 4.122 \\
\hline DIV_AÇÃO & 1.262 & 3.140 & 2.488 \\
\hline MV & 15.562 & 1.591 & 0.102 \\
\hline \multicolumn{4}{|l|}{ Panel B: variables used in Models 4 and 5} \\
\hline Variables & Average & Standard Deviation & $\begin{array}{c}\text { Coefficient of Variation } \\
\text { Absolute Value } \\
\end{array}$ \\
\hline Concent_AC & 0.523 & 0.203 & 0.388 \\
\hline Crisis & 0.273 & - & - \\
\hline Intang $_{\text {it }}$ & -2.412 & 1.683 & 0.698 \\
\hline Price_PL $L_{i t}$ & 0.472 & 0.928 & 1.966 \\
\hline Probab_GI ${ }_{\mathrm{it}}$ & 0.242 & 0.391 & 1.616 \\
\hline $\mathrm{ROI}_{\mathrm{it}}$ & 0.083 & 0.154 & 1.855 \\
\hline Sinc $_{\text {it }}$ & -0.560 & 2.392 & 4.271 \\
\hline \multicolumn{4}{|l|}{ Panel C: other information } \\
\hline Credit Ratings (investment grade) & & $21.48 \%$ of the observations & \\
\hline Credit Ratings de crédito (speculative grade) & & $78.52 \%$ of the observations & \\
\hline
\end{tabular}

Apl_Financ $\mathrm{CP}_{\mathrm{CP}}$ : short-term investments; $\mathrm{NWC}$ : net working capital; $\mathrm{DPR}_{\mathrm{cp}}$ : short-term debts to related parties; $\mathrm{DPR}_{\mathrm{LP}}$ : long-term debts to related parties; Emp_Financ $\mathrm{CP}_{\mathrm{C}}$ : short-term loans and financings; Fcx_op: cash flow generated by operating activities; Imob: fixed assets; LAJIR_DF: ratio between earnings before interests and taxes and financial costs; DIV_AÇÃO: dividend per share; MV: companies'́net equit market value; Concent_AC $\mathrm{i}_{\mathrm{it}}$ : level of ownership concentration; Crisis: period of economic-financial crisis in the Brazilian scenario; Intang $_{\mathrm{it}}$ : percentage of the intangible assets compared with the total assets; Price_P $\mathrm{L}_{\mathrm{it}}$ : ratio between the price per share and the net equity per share; Probab_GI $\mathrm{I}_{\mathrm{i}}$ : probability of the credit rating of company $\mathrm{i}$ for the period $\mathrm{t}$ in taking on investment grade; ROI $\mathrm{I}_{\mathrm{it}}$ : average return on investment of the company $i$ for the period $t$ and; Sinc $_{\mathrm{it}}$ : synchronicity level of the price of the stock $i$ for the period $t$.

It was observed by means of Table 3 that the variable LAJIR_DF presented the greatest coefficient of variation (CV) among the variables used in Model 3 (Panel A). On the other hand, the MV variable presented the lowest CV. It was identified that the variable $\operatorname{Sinc}_{i t}($ Panel B), which measures the stock price synchronicity levels, present a relatively high $\mathrm{CV}$, that is 4.271 . Nonetheless, this characteristic of dispersion of the variable Sinc $_{\text {it }}$ possibly do not leads to bias in the analysis, since robust models regarding the nonnormality and heteroscedasticity of the data (Probit, Logit and Tobit models). Table 3 also indicates that $21.48 \%$ of the observations concerns the credit ratings rated as investment grade and $78.52 \%$ were rated as speculative grade (Panel C).

Next, the results obtained for Model 3 (table 4) are presented. 
Table 4. Results for Model 3: potential credit ratings

\begin{tabular}{ccc}
\hline Variables & Expected signs for the coefficients & Coefficients \\
\hline MV & $(+)$ & $6.497 * * *$ \\
DIV_AÇÃO & $(+)$ & $1.569^{* * *}$ \\
Emp_Financ $\mathrm{CP}$ & $(-)$ & $-1.495^{* *}$ \\
NWC & $(+)$ & $1.407^{* *}$ \\
Constant & $?$ & $-111.077^{* * *}$ \\
Observations & 828 & \\
Wald chi 2(4) & $69.23^{* * *}$ & \\
\hline
\end{tabular}

***Significant at $1 \%$; **Significant at $5 \%$; *Significant at $10 \%$.

MV: market value of the companies'net equity; DIV_AÇÃO: dividends per share; Emp_Financ ${ }_{\mathrm{CP}}$ : short-term loans and financings and; NWC: net working capital.

Source: Elaborated by the authors.

The results presented in Table 4 point that just the variables MV, DIV_AÇÃO, Emp_FinancCP and NWC are associated with the potential credit ratings (the results for the other variables were not tabulated). The variables MV and DIV_AÇÃO are tied, respectively, to the companies'size and distribution policies. The variables Emp_FinancCP and NWC regard the short-term financial balance levels. Nevertheless, this result suggests that the credit ratings are associated with the observable accounting and market variables, that is, there are innitial evidences that the ratings do not fully embody the companies'economic and financial foundations.

An additional analysis related the levels of current and potential credit ratings. This analysis was conducted from Figure 1.

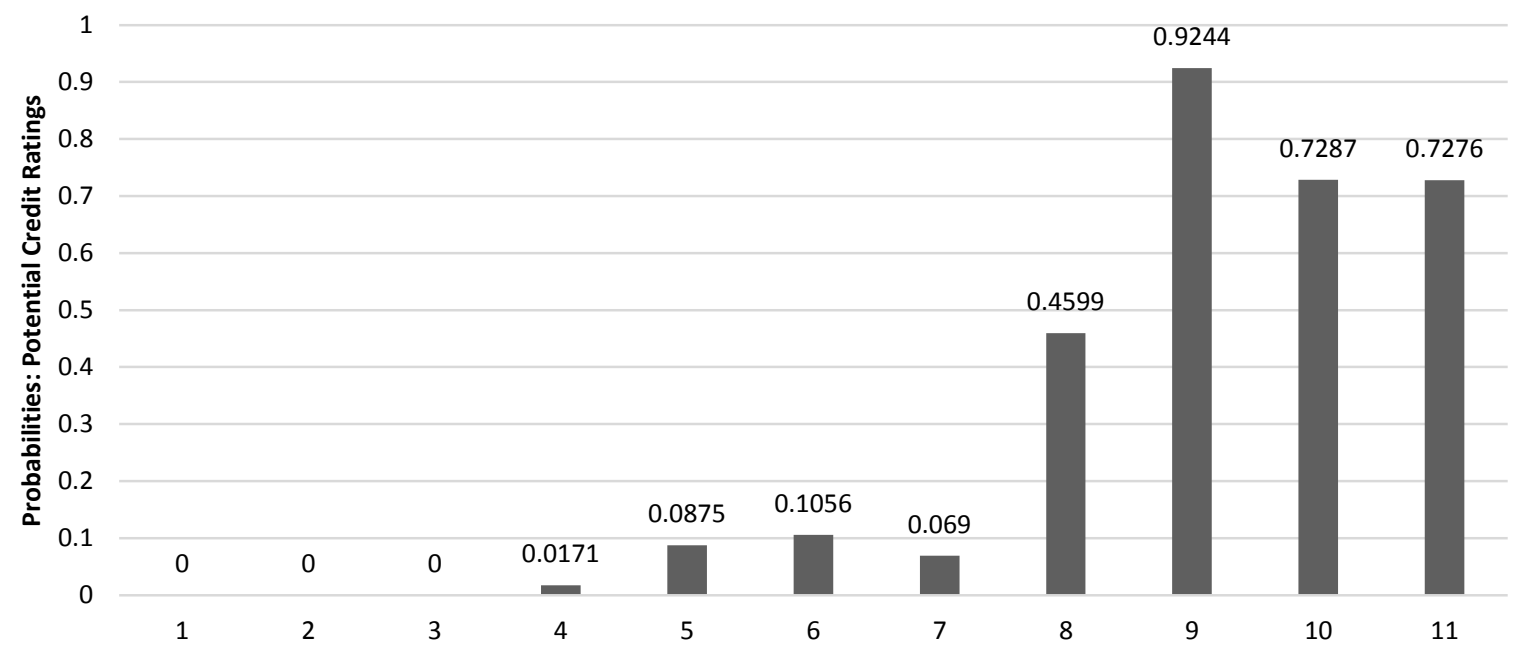

Figure 1. Current and potential credit ratings

1: Caa1 (Moddy's) and CCC+(S\&P); 2: B3 (Moddy's) and B-(S\&P); 3: B2 (Moddy's) and B(S\&P); 4: B1 (Moddy's) and B+(S\&P); 5: Ba3 (Moddy's) and BB-(S\&P); 6: Ba2 (Moddy's) and BB(S\&P); 7: Ba1 (Moddy's) and BB+(S\&P); 8: Baa3 (Moddy's) and BBB-(S\&P); 9: Baa2 (Moddy's) and BBB(S\&P); 10: Baa1 (Moddy's) and BBB+(S\&P) and; 11: A3 (Moddy's) and A-(S\&P).

Source: Elaborated by the authors.

Through Figure 1, it can be observed that the probabilities of the companies in taking on investment grade are positively linked to the current credit ratings. Nevertheless, these probabilites are not equal between the rating classes. For instance, there are evidences of a greater probability that the companies which already have investment grade (from the rating class 8 in Figure 1), remain in this level. Moreover, it was possible to identify that even within each rating class there is a substantial variability regarding the potential credit ratings. This result coroborates the idea that the credit ratings can be, in greater or lower level, foreseen from information publicly available, as suggested by Hovakimian et al. (2009).

Following, the results for Model 4 are presented. 
Table 5. Results for Model 4

\begin{tabular}{|c|c|c|}
\hline \multicolumn{3}{|l|}{ Panel A- Upgrade } \\
\hline Variables & Expected signs for the coefficients & Coefficients \\
\hline Constant & $?$ & $-1.3955^{* * *}$ \\
\hline Sinc $_{\text {it }}$ & $(-)$ & 0.0538 \\
\hline Sinc $_{\text {it }} \times$ GI & $(-)$ & $-0.1781^{* *}$ \\
\hline Probab_GI ${ }_{i t}$ & $(+)$ & $0.3970^{*}$ \\
\hline Beta $_{\text {it }}$ & $(-)$ & $-0.1779^{*}$ \\
\hline Price_PL $L_{i t}$ & $(+)$ & $0.4300 * *$ \\
\hline $\mathrm{ROI}_{\mathrm{it}}$ & $(+)$ & -0.0062 \\
\hline Crisis & $(-)$ & 0.3194 \\
\hline \multicolumn{3}{|c|}{ Panel B- Downgrade } \\
\hline Variables & Expected signs for the coefficients & Coefficients \\
\hline Constant & $?$ & $-0.5280^{* *}$ \\
\hline Sinc $_{\text {it }}$ & $(-)$ & 0.2006 \\
\hline Sinc $_{\text {it }} \times$ GI & $(-)$ & 0.0924 \\
\hline Probab_GI $\mathrm{it}_{\mathrm{it}}$ & $(-)$ & $-3.2950 * * *$ \\
\hline Beta $_{\text {it }}$ & $(+)$ & $0.1871 * *$ \\
\hline Price_PL $L_{i t}$ & $(-)$ & $0.5592 * * *$ \\
\hline $\mathrm{ROI}_{\mathrm{it}}$ & $(-)$ & $-0.2938^{* * *}$ \\
\hline Crisis & $(+)$ & $1.8613 * * *$ \\
\hline \multicolumn{3}{|c|}{ Panel C- Model adjustment measures } \\
\hline Observations & & 828 \\
\hline Statistics chi2(14) & & 260.28 \\
\hline Probability chi2 & & $0.000^{* * *}$ \\
\hline Pseudo $\mathrm{R}^{2}$ & & 0.1908 \\
\hline
\end{tabular}

***Significant at 1\%; ** Significant at 5\%; Significant at $10 \%$.

Sinc $_{\mathrm{it}}$ : synchronicity level of the price of the stock i for the period $t$; GI: binary variable which takes on the value 1 for the credit ratings of the companies rated with investment grade. It takes the value 0 for the other observations; Probab_GI company $i$ for the period $t$ in taking on the investment grade; Beta $_{\mathrm{it}}$ : market beta coefficient for the company $\mathrm{i}$ in the period $\mathrm{t}$. The market beta coefficient was calculated for a three-month period; Price_PL $L_{\mathrm{it}}$ : ratio between the stock price and the net equity per share; $\mathrm{ROI}_{\mathrm{it}}$ : average return on investment of the company $i$ for the period $t$; Crisis: binary variable which takes on the value 1 for the observations regarding the years 2014 and 2015 .

Source: Elaborated by the authors.

The results found for Model 4 point that the stock prices signal alterations in the companies'credit ratings in upgrade conditions. For these positive rating alterations, the coefficient $\beta 2$ ( $\operatorname{Sinc}_{\mathrm{it}} \mathrm{x}$ GI) of Model 4 presented negative sign and statistical significance at $1 \%$. The results obtained evince a negative association between the SPSL and the credit ratings for the companies with investment grade. A possible explanation for this result is that companies with investment grade tend to provide, to the market, a greater amount of and higher-quality relevant information for decision-making compared to companies rated as speculative investment.

Moreover, it was identified that the variable Betait presented negative coefficient and statistical significance at $10 \%$, indicating that greater levels of systematic market risks are associated negatively to the upgrades of the ratings. On the other hand, the variable Price_PLit presented positive coefficient and statistical significance, which suggests that the expectations of the companies'future growth may be positively associated with the ratings alterations.

Regarding the downgrades, significant results which evince that the stock prices reflect these negative alterations of the ratings were not found. Thus, the coefficients of the variables related to the SPSL did not show to be different from zero. A plausible explanation for that is that the investors can recognize that these downgrades do not set up as a permanent situation for the companies. Still regarding the downgrades, it was identified that the coefficient of the variables Probab_GIit and ROIit presented negative sign and statistical significance, whereas the variables Beta ${ }_{i t}$, Price_PLit and Crisis presented positive sign for their coefficients and statistical significance.

Overall, the results obtained in Model 4 support this study's Hypothesis 1 regarding the upgrades. In contrast, no elements which could support the Hypothesis 2 were found. 
Finally, the results for Model 5 are presented.

Table 6. Results for Model 5

\begin{tabular}{|c|c|c|}
\hline Variables & Expected coefficient signs & Coefficients \\
\hline Constant & $?$ & $0.6086^{* * *}$ \\
\hline Sinc $_{\text {it }}$ & $(-)$ & 0.0133 \\
\hline $\operatorname{Sinc}_{\mathrm{it}} \times \mathrm{GI}$ & $(-)$ & $-0.0395 * * *$ \\
\hline Beta $_{\text {it }}$ & $(-)$ & $-0.3587 * * *$ \\
\hline Price_PL $L_{i t}$ & $(+)$ & 0.0181 \\
\hline $\mathrm{ROI}_{\mathrm{it}}$ & $(+)$ & $0.0097 * * *$ \\
\hline Concent_AC $\mathrm{C}_{\mathrm{it}}$ & $(-)$ & $-0.5125 * * *$ \\
\hline Intang $_{\text {it }}$ & $(+)$ & 0.0048 \\
\hline Observations & \multicolumn{2}{|c|}{828} \\
\hline Statistics chi2 & \multicolumn{2}{|c|}{$266.48^{* * *}$} \\
\hline Pseudo $\mathrm{R}^{2}$ & \multicolumn{2}{|c|}{$49.59 \%$} \\
\hline
\end{tabular}

*** Significant at $1 \%$; ** Significant at $5 \%$; Significant at $10 \%$.

Sinc $\mathrm{i}_{\mathrm{i}}$ : synchronicity level of the price of the stock i for the period t; GI: binary variable which takes on value 1 for the credit ratings of the companies rated as investment grade. It takes value 0 for the other observations. Beta $a_{i t}$ market beta coefficient for the company $i$ in the period t. The market beta coefficient was calculated for a three-month period; Price_PL $\mathrm{L}_{\mathrm{it}}$ : ratio between the price per share and the net equity per share; $\mathrm{ROI}_{\mathrm{it}}$ : average return on investment of the company i for the period $\mathrm{t}$; Concent_AC $\mathrm{i}_{\mathrm{it}}$ : concentration level of the voting capital of company $\mathrm{i}$ for the period t. For the calculation of this variable, the average accumulated participation of the three main shareholders in the voting capital was considered and; Intang $_{\mathrm{it}}$ : percentage of the intangible assets in relation to the total assets. For this variable, the logarithm scale was used.

Source: Elaborated by the authors.

For the Model 5, evinces that the SPSL were negatively associated with the companies'potential credit ratings. This result was significant for the companies rated as investment grade. Thus, the capital market may be a more suitable source of information on the alterations of the companies'ratings compared to the risk-rating agencies. Studies such as Driss et al. (in press), Alissa et al. (2013) and Hovakimian et al. (2009) indicate that the review of the credit ratings levels by the risk-rating agencies takes place very slowly, which would imply that the ratings may not suitably embody the default probability of credit borrowers. Moreover, it was identified that the variables Beta ${ }_{i t}$, Concent_ACit (negative relationship) and ROIit (positive relationship) presented statistical associations with the companies'potential credit ratings.

With the results found in Model 5, there were evidences which support the Hypothesis 3.

\subsection{Additional Tests}

As a means of validation of the results reached in the present study, a metric which refers to the informativeness levels of the stock prices was elaborated. This metric was based on the work of Jin and Myers (2006) and was defined in the following way:

$$
R_{i t}-R f_{t}=\alpha+\beta_{1}\left(R M_{t}-R f_{t}\right)+\beta_{2}\left(R M_{t-1}-R f_{t-1}\right)+\beta_{3} \text { Crisis }+\sum_{i}^{n} \text { dummy } y_{\text {sector }}+\varepsilon_{t}
$$

in which: Rit: return of the stock $\mathrm{i}$ for the period $\mathrm{t}$; Rft and Rft-1: risk-free rate for the periods $\mathrm{t}$ and $\mathrm{t}-1$, respectively. The interest rate of the Interbank Deposit Certificate (CDI) was used as representative of the risk-free rate; RMt and RMt-1: return of the market portfolio for the periods $\mathrm{t}$ and $\mathrm{t}-1$, respectively, and the returns of the Ibovespa index were used as representatives of the market portfolio returns; Crisis: binary variable which takes on value 1 for the observations regarding the years 2014-2015. It takes on value 0 for the other observations; dummysector: binary variables representative of the companies' economic activity sector and; $\varepsilon_{t}$ : error term.

For the estimate of the coefficients of Model 6, the regression technique with panel data from the random effects was used. Moreover, the error term $\left(\varepsilon_{t}\right)$ of Model 6 represents a proxy variable in the measurement of the stock price informativeness in reflecting the companies'specific information. Afterwards, it was examined whether the stock prices bring relevant information regarding the companies'potential ratings under study. Therefore, a Tobit model, which is defined as follows, was used:

$$
\begin{gathered}
\text { Probab }_{G I i t}=\alpha+\beta_{1} \operatorname{Inf}_{t}+\beta_{2} \text { Inf }_{t-1}+\beta_{3} \text { Inf }_{t-2}+\beta_{4} \operatorname{Inf}_{t-3}+\beta_{5} \operatorname{Inf}_{t-4}+\beta_{6} \text { Beta }_{i t}+\beta_{7} \text { Price }_{P L_{i t}}+ \\
\beta_{8} \text { ROI I }_{i t}+\beta_{9} \text { Concent }_{-} A C_{i t}+\beta_{10} \text { Intang }_{i t}+\varepsilon_{t}
\end{gathered}
$$


in which: Probab_Glit: probability of the credit rating of the company $\mathrm{i}$ for the period $\mathrm{t}$ in taking on the investment grade; Inft, Inft-1, Inft-2, Inft-3 and Inft-4: stock price informativess. The variable Inft does not present lag in the period, whereas the variables Inft-1, Inft-2, Inft-3 and Inft-4 present, respectively, lags of 1 to 4 periods; Beta $_{\mathrm{it}}$ : market beta coefficient for the company $\mathrm{i}$ in the period $\mathrm{t}$. It is worth to highlight that the market beta coefficient was calculated for a three-month period; Price_PLit: ratio between the stock price and the net equity per share; ROIit: average return on investment of company i for the period t; Concent_ACit: concentration level of the voting capital of the company i for the period t. For the calculation of this variable, the average accumulated participation of the three main shareholders was considered; Intangit: percentage of the intangible assets in relation to the total assets. For this variable, the logarithm scale was used and; $\varepsilon_{t}$ : error term.

For the Model 7, it was expected that the variables Inft, Inft-1, Inft-2, Inft-3 and Inft-4 presented coefficients with positive sign and statistical significance. This result would indicate that the stock prices embody relevant information regarding the companies' potential credit ratings. Moreover, it indicates that the capital market may reflect, with some antecipation, these types of credit ratings. The control variables (Beta $a_{i t}$, Price_PLit, ROIit, Concent_ACit and Intang ${ }_{i t}$ ) which were used in Model 7 aimed to examine the factors associated with the companies'potential credit ratings. Nevertheless, it was assumed that such control variables are not entirely reflected in the variables which represent the informativeness of the stock prices (Inft, Inft-1, Inft-2, Inft-3 and Inft-4). For the variables Beta ${ }_{i t}$ and Concent_ACit coefficients with negative sign were expected, while for the

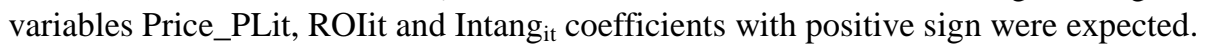

First, the results obtained in Model 6 are presented.

Table 7. Results for Model 6

\begin{tabular}{cccc}
\hline Variables & Expected coefficient signs & Coefficients & Robust Standard Error \\
\hline Constant & + & $0.0359^{* * *}$ & 0.0081 \\
$\left(\mathrm{RM}_{\mathrm{t}}-\mathrm{Rf}_{\mathrm{t}}\right)$ & + & $0.8740^{* * *}$ & 0.0454 \\
$\left(\mathrm{RM}_{\mathrm{t}-1}-\mathrm{Rf}_{\mathrm{t}-1}\right)$ & + & $0.1661^{* * *}$ & 0.0391 \\
Crisis & - & $-0.0459^{* * *}$ & 0.0126 \\
Binary variables for sector & Yes & \\
Panel data & Random Effects \\
Observations & 828 \\
Probability chi2 (qui-square) & $0.000^{* * *}$ & \\
$\mathrm{R}^{2}$ Overall & & 0.3651 & \\
\hline
\end{tabular}

***Significant at $1 \%$;* Significant at 5\%; Significant at $10 \%$.

Rft e Rft-1: risk-free rate for the periods t and t-1, respectively. The interest rate of the Interbank Deposit Certificate (CDI) was used as representative of the risk-free rate; RMt and RMt-1: return of the market portfolio for the periods $\mathrm{t}$ and $\mathrm{t}-1$, respectively, and the returns of the Ibovespa index were used as representatives of the market portfolio returns; Crisis: binary variable which takes on value 1 for the observations regarding the years 2014-2915, It takes on value 0 for the other observations; dummysector: binary variables representative of the companies' economic activity sector and; $\varepsilon_{t}$ : error term.

Source: Elaborated by the authors.

Model 6 presented statistically significant chi2 (qui-square) probability, indicating the model adjustment of the data used. The model's explanatory power is $36.5 \%$. The coefficient of the variables presented the expected sign and statistical significance, at 1\%. For the Model 6, a reduction of the market premiums for the 2014-2015 period, which correspond to periods of crisis for the Brazilian financial market, was identified. Afterwards, the error term of the Model 6 was used in the development of the stock price informativeness variable (Inf). These results are presented next. 
Table 8. Results for Model 7

\begin{tabular}{|c|c|c|c|c|}
\hline Variables & $\begin{array}{c}\text { Expected } \\
\text { coefficient signs }\end{array}$ & $\begin{array}{c}\text { Full Sample Coefficients } \\
\text { (Standard Error) }\end{array}$ & $\begin{array}{c}\text { Investment Grade Coefficients } \\
\text { (Standard Error) }\end{array}$ & $\begin{array}{c}\text { Speculative Grade Coefficients } \\
\text { (Standard Error) }\end{array}$ \\
\hline \multirow{2}{*}{ Constant } & \multirow{2}{*}{+} & $0.5182 * * *$ & $1.1485^{* * * *}$ & $0.1161 * *$ \\
\hline & & $(0.0735)$ & $(0.1364)$ & $(0.0517)$ \\
\hline \multirow{2}{*}{$\operatorname{Inf}_{\mathrm{t}}$} & \multirow{2}{*}{+} & $0.2266^{* *} *$ & $0.5143 * *$ & $0.1237^{*}$ \\
\hline & & $(0.1032)$ & $(0.2013)$ & $(0.0750)$ \\
\hline \multirow{2}{*}{$\operatorname{Inf}_{\mathrm{t}-1}$} & \multirow{2}{*}{+} & $0.2535 * *$ & $0.4256 * *$ & $0.1990 * * *$ \\
\hline & & $(0.1059)$ & $(0.2030)$ & $(0.0747)$ \\
\hline \multirow{2}{*}{$\operatorname{Inf}_{\mathrm{t}-2}$} & \multirow{2}{*}{+} & 0.0700 & $0.4508 * *$ & 0.0636 \\
\hline & & $(0.1192)$ & $(0.2114)$ & $(0.0831)$ \\
\hline \multirow{2}{*}{$\operatorname{Inf}_{\mathrm{t}-3}$} & \multirow{2}{*}{+} & -0.0036 & -0.0268 & 0.0182 \\
\hline & & $(0.1162)$ & $(0.2331)$ & $(0.0803)$ \\
\hline \multirow{2}{*}{$\operatorname{Inf}_{\mathrm{t}-4}$} & \multirow{2}{*}{+} & -0.0101 & 0.0140 & -0.0985 \\
\hline & & $(0.1215)$ & $(0.2493)$ & $(0.0852)$ \\
\hline \multirow{2}{*}{ Beta $_{\text {it }}$} & \multirow[b]{2}{*}{-} & -0.0227 & 0.0381 & -0.0160 \\
\hline & & $(0.0140)$ & $(0.0291)$ & $(0.102)$ \\
\hline \multirow{2}{*}{ Price_PL ${ }_{i t}$} & \multirow{2}{*}{+} & $0.0779 * * *$ & $0.1336^{* * *}$ & -0.0288 \\
\hline & & $(0.0268)$ & $(0.0475)$ & $(0.0211)$ \\
\hline \multirow{2}{*}{$\mathrm{ROI}_{\mathrm{it}}$} & \multirow{2}{*}{+} & $0.0158^{* * *}$ & $0.0142 * * *$ & $0.0092 * * *$ \\
\hline & & $(0.0024)$ & $(0.0038)$ & $(0.0017)$ \\
\hline \multirow{2}{*}{ Concent_AC $\mathrm{At}_{\mathrm{it}}$} & \multirow[b]{2}{*}{ - } & $-0.3899 * * *$ & $-0.9095 * * *$ & -0.0382 \\
\hline & & $(0.1017)$ & $(0.2059)$ & $(0.0713)$ \\
\hline \multirow{2}{*}{ Intang $_{\text {it }}$} & \multirow{2}{*}{+} & $0.0543^{* * *}$ & $0.0916^{* * *}$ & $0.0162 *$ \\
\hline & & $(0.0118)$ & $(0.0217)$ & $(0.0083)$ \\
\hline Observations & & 828 & 178 & 650 \\
\hline Statistics chi2 & & $85.97 * * *$ & $48.54 * * *$ & $56.31 * * *$ \\
\hline Pseudo $\mathrm{R}^{2}$ & & 0.1531 & 0.1835 & 0.0547 \\
\hline
\end{tabular}

*** Significant at $1 \%$;* Significant at 5\%; * Significant at $10 \%$.

$\operatorname{Inf}_{\mathrm{t}}, \operatorname{Inf}_{\mathrm{t}-1}, \operatorname{Inf}_{\mathrm{t}-2}, \operatorname{Inf}_{\mathrm{t}-3}$ e $\operatorname{Inf}_{\mathrm{t}-4}$ : stock price informativeness. The variable $\operatorname{Inf}_{\mathrm{t}}$ does not present period lag, whereas the variables $\operatorname{Inf}_{\mathrm{t}-1}, \operatorname{Inf}_{\mathrm{t}-2}, \operatorname{Inf}_{\mathrm{t}-3}$ and $\operatorname{Inf}_{\mathrm{t}-4}$ present, respectively, lags from 1 to 4 periods; Beta ${ }_{\mathrm{it}}$ : market beta coefficient for the company $\mathrm{i}$ in the period $\mathrm{t}$. The market beta coefficient was calculated for a three-month period; Price_P $\mathrm{L}_{\mathrm{i} t}$ : ratio between the stock price and the net equity per share; $\mathrm{ROI}_{\mathrm{it}}$ : average return on investment of the company $i$ for the period $t$; Concent_AC $\mathrm{AC}_{\mathrm{it}}$ : concentration level of the voting capital of the company $\mathrm{i}$ for the period $\mathrm{t}$. For the calculation of this variable, the average accumulated participation of the companies'three main shareholders was considered; Intang it $^{\text {: }}$ percentage of the intangible assets in relation to the total assets. For this variable, the logarithm scale was used.

Source: Elaborated by the authors.

The results presented in Table 8 indicate a statistically significant and positive relationship between the share price informativeness levels and the companies'potential credit ratings. Nonetheless, the results did not show to be equivalent when segregating the companies rated as investment grade and speculative grade. Regarding the sample of the companies rated as investment grade, the variables Inft, Inft-1, Inft-2 are statistically significant at $5 \%$. Regarding the companies rated as speculative grade, it was identified that the variables Inft and Inft-1 are statistically significant at $10 \%$ and $1 \%$, respectively. Nevertheless, the Wald test was carried out and it indicated that the coefficients for the variable Inf are statistically different at $1 \%$ for those two credit ratings. To elucidate this matter, Figure 2 presents the estimated coefficients for the variables Inft, Inft-1, Inft-2, Inft-3 and Inft-4.

As Figure 2 evinces, the stock prices may convey relevant information on the companies'potential credit ratings, specially for those rated as investment grade. Thus, the results found for the share price informativeness metric (Inf) corroborate the results found for the stock price synchronicity metric (Sinc). 


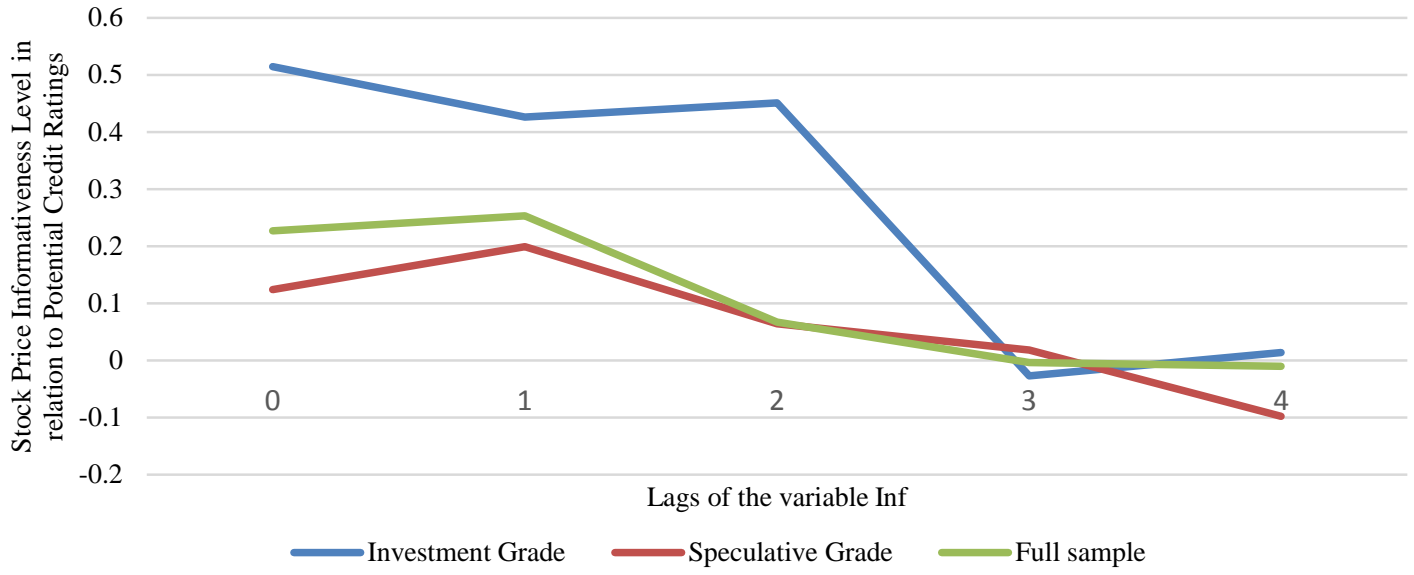

Figure 2. Stock price informativeness in relation to potential credit ratings

Inf: stock price informativeness

Source: Elaborated by the authors.

An important economic implication for the results, as presented in Figure 2, is that the capital market can become a kind of market monitor, regarding the stock price informativeness, whose quality is worse to the companies rated as speculative grade than to investment grade ones. This would be a plausible explanation for the oppotunistic action of the companies'managers concerning the practices of result management (Alissa et al., 2013), financial leverage levels (Hung et al., 2017), aspects of corporate governance (Ham \& Koharki, 2016), among other aspects.

Another matter which was examined was whether the inferences carried out from the results reached are biased by identification problems, in terms of the relationship between the variables related to the information levels reflected on the stock prices (Sinc and Inf) and the companies'credit ratings. Thus, the Granger causality test for panel data was used, based on the recommendations of Dumitrescu and Hurlin (2012). The results are presented in Table 9.

Table 9. Granger causality test in panel data

\begin{tabular}{ccc}
\hline Statistics & $\begin{array}{c}\text { Causality Direction } \\
\text { SPSL } \rightarrow \text { Ratings } \\
(\mathbf{1 ~ l a g})\end{array}$ & $\begin{array}{c}\text { Causality Direction } \\
\text { Ratings } \rightarrow \text { SPSL } \\
(\mathbf{1 ~ l a g})\end{array}$ \\
\hline W-bar & 0.3666 & 1.2720 \\
Z-bar & $-2.6115^{* * *}$ & 1.1217 \\
Z-bar tilde & $-2.5293^{* *}$ & 0.5200 \\
\hline
\end{tabular}

*** Significant at level of 1\%; ** Significant at level of 5\%; * Significant at level of $10 \%$.

SPSL: stock price synchronicity levels; Ratings: the companies'credit ratings levels.

Source: Elaborated by the authors.

The results of the Granger causality test indicated that the SPSL influence the companies'current credit ratings. The results did not evince an inverse relationship. From this, there are no evidences of identification problems between the variables analyzed.

\section{Final Considerations}

It seems to be a matter open to endless discussions to the consideration that credit ratings bring relevant and timely information on decision-making of the economic agents in the financial markets. The companies'credit ratings reviewing process by the risk-rating agencies tend to be slow and not to embody all the relevant information on the companies'default probabilities. These characteristics of the credit ratings can be exarcebated for less developed countries, which generally present an informational environment of less transparency, low levels of legal enforcement and ownership rights when compared to developed markets.

Nonetheless, the results reached by the present study point that the stock prices can signal, with some antecipation, the credit ratings alterations. This effect was detected by lower SPSL associated with alterations 
(upgrade and downgrade) in the current credit ratings. The stock prices would tend to reflect the potential credit ratings as well.

Another characteristic of the results found between the SPSL and the credit ratings is that they are associated with companies rated as investment grade. This fact points that not all the credit risk ratings present relevant informational content for the decision-making of stock investors. It is worth highlighting that the result robustness was additionally tested from additional tests such as informativeness and Granger causality for panel data.

The generalization of this study's results must be seen with caution, mainly when countries which present substantial differences regarding the informational environment, as it is observed in the Brazilian scenario, are taken into account. Another limitation of the study is the consideration that the relationship between credit ratings and SPSL is monotonic (strictly negative). This question of the monotonicity of SPSL with respect to company specific-information permeates a rich academic debate, as can be seen in the work of Kelly (2014), Xing and Anderson (2011), among others.

For future researches, it would be interesting to investigate how the mechanism of stock price formation embodies relevant information on the companies'credit ratings during recession and financial crisis periods. It is also interesting to compare how the stocks of peer firms reflect credit rating information. The issues are quite incipient not only in the Brazilian scenario, but for undeveloped and emerging markets.

\section{References}

Alissa, W., Bonsall IV, S. B., Koharki, K., \& Penn Jr., M. W. (2013). Firm's use of accounting discretion to influence their credit ratings. Journal of Accounting and Economics, 55(2-3), 129-147. https://doi.org/10.1016/j.jacceco.2013.01.001

An, H., \& Chan, K. C. (2008). Credit ratings and IPO pricing. Journal of Corporate Finance, 14(5), 584-595. https://doi.org/10.1016/j.jcorpfin.2008.09.010

Antônio, R. M., Ambrozini, M. A., Magnani, V. M., \& Rathke, A. A. T. (2019). Does the use of hedge derivatives improve the credit ratings of Brazilian companies? Revista Contabilidade \& Finanças, Epub June 27, 2019. https://dx.doi.org/10.1590/1808-057x201908740

Balios, D., Thomadakis, S., \& Tsipouri, L. (2016). Credit rating model development: an ordered analysis based on accounting data. Research in International Business and Finance, 38, 122-136. https://doi.org/10.1016/j.ribaf.2016.03.011

Bolton, P., Freixas, X., \& Shapiro, J. (2012). The credit ratings game. The Journal of Finance, 67(1), 85-111. https://doi.org/10.1111/j.1540-6261.2011.01708.x

Brito, G. A. S., Assaf Neto, A., \& Corrar, L. J. (2009). Sistema de classificação de risco de crédito: Uma aplicação a companhias abertas no Brasil. Revista Contabilidade \& Finanças, 20(51), 28-43. http://dx.doi.org/10.1590/S1519-70772009000300003

Cameron, A. C., \& Trivedi, P. K. (2010). Microeconometrics using Stata (Revised Edition). Texas: Stata Press.

Cantor, R. (2004). An introduction to recent research on credit ratings. Journal of Banking \& Finance, 28(11), 2565-2573. https://doi.org/10.1016/j.jbankfin.2004.06.002

Chan, K., \& Hameed, A. (2006). Stock price synchronicity and analyst coverage in emerging markets. Journal of Financial Economics, 80(1), 115-147. https://doi.org/10.1016/j.jfineco.2005.03.010

Driss, H., Massoud, N., \& Roberts, G. S. (in press). Are credit rating agencies still relevant? Evidence on certification from Moody's credit watches. Journal of Corporate Finance. https://doi.org/10.1016/j.jcorpfin.2016.08.003

Dumitrescu, E. I., \& Hurlin, C. (2012). Testing for Granger non-causality in heterogeneous panels. Economic Modelling, 29(4), 1450-1460. https://doi.org/10.1016/j.econmod.2012.02.014

Elshandidy, T. (2014). Value relevance of accounting information: evidence from an emerging market. Advances in Accounting, Incorporating Advances in International Accounting, 30(1), 176-186. https://doi.org/10.1016/j.adiac.2014.03.007

Fama, E. F. (1970). Efficient capital markets: A review of theory and empirical work. The Journal of Finance, 25(2), 383-417.

Fernandes, N., \& Ferreira, M. A. (2008). Does international cross-listing improve the information environment? 
Journal of Financial Economics, 88(2), 216-244. https://doi.org/10.1016/j.jfineco.2007.06.002

Figlioli, B., \& Lima, F. G. (2019). Stock pricing in Latin America: The synchronicity effect. Emerging Markets Review, 39, 1-17. https://doi.org/10.1016/j.ememar.2019.03.002

Fracassi, C., Petry, S., \& Tate, G. (2016). Does rating analyst subjectivity affect corporate debt pricing? Journal of Financial Economics, 120, 514-538. https://doi.org/10.1016/j.jfineco.2016.02.006

Galil, K., \& Soffer, G. (2011). Good news, bad news and rating announcements: An empirical investigation. Journal of Banking \& Finance, 35(11), 3101-3119. https://doi.org/10.1016/j.jbankfin.2011.04.010

Ghio, A., \& Verona, A. (2015). Accounting harmonization in the BRIC countries: A common path? Accounting Forum, 39(2), 121-139. https://doi.org/10.1016/j.accfor.2015.02.001

Graham, J. R., \& Harvey, C. R. (2001). The theory and practice of corporate finance: Evidence from the field. Journal of Financial Economics, 60(2-3), 187-243. https://doi.org/10.1016/S0304-405X(01)00044-7

Ham, C., \& Koharki, K. (2016). The association between corporate general counsel and firm credit risk. Journal of Accounting and Economics, 61, 274-293. https://doi.org/10.1016/j.jacceco.2016.01.001

Hammami, Y., \& Bahri, M. (2016). On the determinants of expected corporate bond returns in Tunisia. Research in International Business and Finance, 38, 224-235. https://doi.org/10.1016/j.ribaf.2016.04.015

Hasan, I., Song, L., \& Wachtel, P. (2014). Institutional development and stock price synchronicity: Evidence from China. Journal of Comparative Economics, 42(1), 92-108. https://doi.org/10.1016/j.jce.2013.07.006

Hovakimian, A., Kayhan, A., \& Titman, S. (2009). Credit rating targets. [Working Paper]. https://doi.org/10.2139/ssrn.1098351.

Hung, CH. D., Banerjee, A., \& Meng, Q. (2017). Corporate financing and anticipated credit rating changes. Review of Quantitative Finance and Accounting, 48, 893-915. https://doi.org/10.1007/s11156-016-0571-3

Instituto Brasileiro de Geografia e Estatística (IBGE). (2017). Séries históricas e estatísticas. Recovered from http://seriesestatisticas.ibge.gov.br.

Jin, L., \& Myers, S. C. (2006). $\mathrm{R}^{2}$ around the world: new theory and new tests. Journal of Financial Economics, 79(2), 257-292. https://doi.org/10.1016/j.jfineco.2004.11.003

Jollineau, S. J., Tanlu, L. J., \& Winn, A. (2014). Evaluating proposed remedies for credit rating agency failures. The Accounting Review, 89(4), 1399-1420. https://doi.org/10.2308/accr-50721

Kedia, S., Rajgopal, S., \& Zhou, X. (2017). Large shareholders and credit ratings. Journal of Financial Economics, 124, 632-653. https://doi.org/10.1016/j.jfineco.2017.03.007

Kelly, P. J. (2014). Information efficiency and firm-specific return variation. Quartely Journal of Finance, 4(4), 1450018. https://doi.org/10.1142/S2010139214500189

Kim, J. B., \& Shi, H. (2012). IFRS reporting, firm-specific information flows, and institutional environments: International evidence. Review of Accounting Studies, 17(3), 474-517. https://doi.org/10.1007/s11142-012-9190-y

Kisgen, D. (2006). Credit ratings and capital structure. Journal of Finance, 61(3), 1035-1072. https://doi.org/10.1111/j.1540-6261.2006.00866.x

Lopes, A. B. (2006). Financial accounting in Brazil: an empirical examination. Latin American Business Review, 6(4), 45-68. https://doi.org/10.1300/J140v06n04_03

Luitel, P., Vanpée, R., \& Moor, L, D. (2016). Pernicious effects: how the credit rating agencies disadvantage emerging markets. Research in International Business and Finance, 38, 286-298. https://doi.org/10.1016/j.ribaf.2016.04.009

Marcet, F. (2017). Analyst coverage network and stock return comovement in emerging markets. Emerging Markets Review, 32, 1-27. https://doi.org/10.1016/j.ememar.2017.05.002

Morck, R., Yeung, B., \& Yu, W. (2000). The information content of stock markets: Why do emerging markets have synchronous stock price movements? Journal of Financial Economics, 58, 215-260. https://doi.org/10.1016/S0304-405X(00)00071-4

Pan, L. H., Lin, C. T., Lee, S. C., \& Ho, K. C. (2015). Information ratings and capital structure. Journal of Corporate Finance, 31, 17-32. https://doi.org/10.1016/j.jcorpfin.2015.01.011

Roll, R. (1988). R². The Journal of Finance, 43(3), 541-566. https://doi.org/10.1111/j.1540-6261.1988.tb04591.x 
Salvador, C. (2017). Effect of signals of bank ratings on stock returns before and during the financial crisis. The Spanish Review of Financial Economics, 15, 1-11. https://doi.org/10.1016/j.srfe.2017.01.002

Stolper, A. (2009). Regulation of credit rating agencies. Journal of Banking \& Finance, 33, 1266-1273. https://doi.org/10.1016/j.jbankfin.2009.01.004

Tang, T. T. (2009). Information asymmetry and firms' credit market access: evidence from Moody's credit rating format refinement. Journal of Financial Economics, 93(2), 325-351. https://doi.org/10.1016/j.jfineco.2008.07.007

Wang, J. W., \& Yu, W. W. (2015). The information content of stock prices, legal environments and accounting standards: International evidence. European Accounting Review, 24(3), 471-493. https://doi.org/10.1080/09638180.2014.977802

Xing, X., \& Anderson, R. (2011). Stock price synchronicity and public firm-specific information. Journal of Financial Markets, 14(2), 259-276. https://doi.org/10.1016/j.finmar.2010.10.001

\section{Copyrights}

Copyright for this article is retained by the author(s), with first publication rights granted to the journal.

This is an open-access article distributed under the terms and conditions of the Creative Commons Attribution license (http://creativecommons.org/licenses/by/4.0/). 